\title{
Biological activities of substituted trichostatic acid derivatives
}

\author{
CÉDRIC CHARRIER ${ }^{\mathrm{a}}$, JOËLLE ROCHE ${ }^{\mathrm{b}}$, JEAN-PIERRE GESSON $^{\mathrm{a}}$ and \\ PHILIPPE BERTRAND ${ }^{\text {a }}$ \\ ${ }^{a}$ Synthèse et Réactivité des Substances Naturelles, CNRS UMR 6514, Université de Poitiers: \\ 40 Avenue du Recteur Pineau, Poitiers, F-86022, France \\ ${ }^{\mathrm{b}}$ Institut de Physiologie et Biologie Cellulaires, CNRS UMR 6187, Université de Poitiers: \\ 40 Avenue du Recteur Pineau, Poitiers, F-86022, France \\ e-mail: philippe.bertrand@univ-poitiers.fr
}

MS received 10 December 2008; accepted 28 April 2009

\begin{abstract}
New substituted trichostatic acid derivatives have been synthesized and evaluated for their biological activities towards the H661 non-small lung cancer cell line. These syntheses were achieved by alkylation of propiophenones to introduce the side chain with a terminal precursor of hydroxamic acid and aminobenzamide derivatives. The first fluorinated derivatives of trichostatic acid are described, such as 6-fluoro trichostatin A, with antiproliferative activities in the micromolar range and with histone deacetylase inhibitory activity.
\end{abstract}

Keywords. Trichostatic acid; HDAC; inhibitor.

\section{Introduction}

Reversible chemical modifications of DNA and histones are important cellular events that promote activation or repression of DNA transcription and are responsible for epigenetic modifications that are altered during cancer progression. ${ }^{1,2}$ Histone acetylation, involved in chromatin decondensation, is associated to active chromatin and is mediated by Histone Acetyl Transferases (HAT). On the contrary, histone deacetylation by Histone Deacetylases (HDAC) leads to a transcriptionally inactive and condensed form of chromatin, ${ }^{3-6}$ In addition, histones are not the only substrates for HAT/HDAC as more than 50 target proteins with diverse functions have been described and include for example, tubulin and p53. ${ }^{7}$ Overexpression of HDAC has been reported in cancers and HDAC inhibition has emerged as a promising anti-cancer treatment. ${ }^{8,9}$ The eighteen HDAC identified in humans are classified in four classes, class I, II and IV being zinc dependent metalloproteins, while class III is NAD dependent. ${ }^{5}$ Several programs were initiated worldwide to develop HDAC inhibitors (HDACi) with particular focus on inhibitors targeting the zinc dependent classes for anti-cancer applications. Natural products

*For correspondence were isolated from fungus like trichostatin A (TSA) 1. Synthetic compounds, like SAHA 2, ${ }^{10,11}$ MS-275 3, and NVP-LAQ824 4 (figure 1) have reached clinical trials. ${ }^{12}$ SAHA was recently approved for treatment of cutaneous T-cell lymphoma. ${ }^{13} \mathrm{TSA}^{14}$ is well known as a HDACi. ${ }^{15,16}$ TSA has been synthesized in either racemic ${ }^{17}$ or enantiopure ${ }^{18}$ form, and enantioselective preparation of trichostatin $\mathrm{D}$, a $\mathrm{O}-\alpha$-glucoside derivative of $\mathrm{TSA}^{19}$ has also been described.

In this article we described the synthesis of new trichostatic acid derivatives and their evaluation as antiproliferative agents and HDAC inhibitors. In a previous work we described indanone analogues of TSA 5a and $\mathbf{6} \mathbf{a}^{20}$ (figure 2) with antiproliferative activities on $\mathrm{H} 661$ lung cancer cells $\left(\mathrm{IC}_{50}=0.3\right.$ and $2.5 \mu \mathrm{M}$ respectively) and HDACi property. We planned to compare the activity of these reported compounds to new 6-substituted TSA analogues with no additional ring constraint.

\section{Experimental}

Abbreviations used: PE: petroleum ether, EtOAc: ethyl acetate, THF : tetrahydrofuran, TBTU: tetrafluoroborate O-(benzotriazol-1-yl-1,1,3,3-tetramethyl)-uronium, EDC: 1-[3(dimethylamino)propyl]3-ethyl-carbodiimide hydrochloride. 


\subsection{1-(4-Dimethylaminophenyl)-propan-1-one 9}

Method A: To a solution of aldehyde $7(3.05 \mathrm{~g}$, $20.5 \mathrm{mmol})$ in THF $(20 \mathrm{ml})$ was added a THF solution of BrMgEt freshly prepared $(31 \mathrm{ml}, 61.5 \mathrm{mmol}$, $2 \mathrm{~N}$ in THF). The mixture was refluxed $4 \mathrm{~h}$ under nitrogen and then cooled. A saturated solution of $\mathrm{NH}_{4} \mathrm{Cl}$ was then added to obtain neutralization $(15 \mathrm{ml})$. The resulting mixture was extracted $($ EtOAc, $3 \times 100 \mathrm{ml})$ and the combined organic lay-

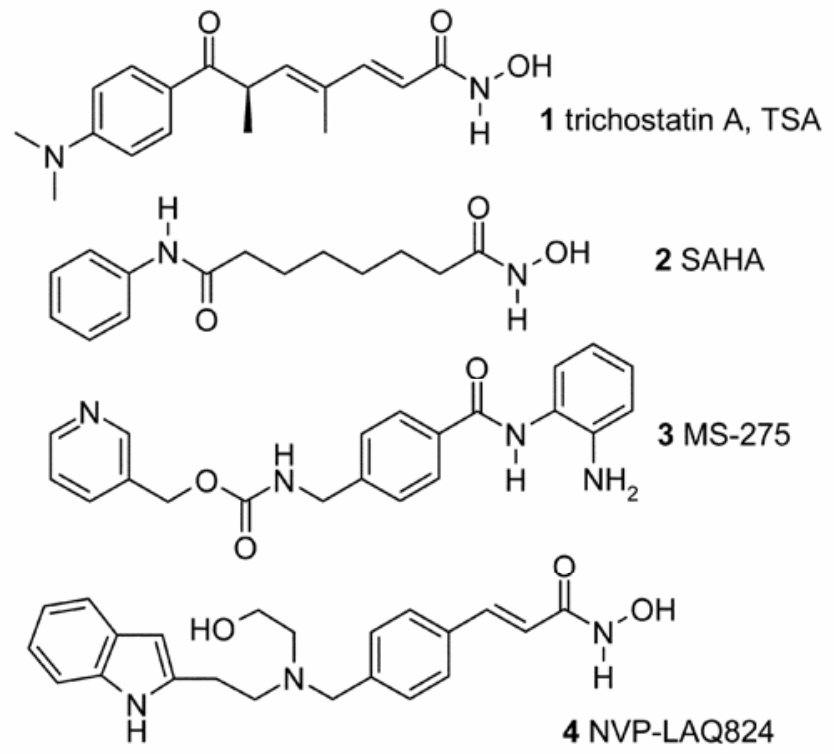

Figure 1. Natural and synthetic HDACi.

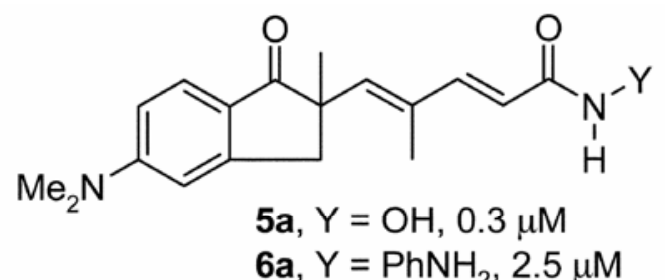<smiles>[R]C(=O)C(C)C(=O)c1ccc(N(C)C)cc1</smiles>

Figure 2. Targeted TSA derivatives. ers were dried $\left(\mathrm{MgSO}_{4}\right)$ and concentrated under reduced pressure to give the crude alcohol that was purified (flash chromatography on silica, EtOAc: PE $10: 90)$. The alcohol 8 was obtained as a colourless oil (3.6 g, 98\%).

The intermediate alcohol $8(3.6 \mathrm{~g}, 20 \mathrm{mmol})$ was dissolved in $\mathrm{tBuOH}(20 \mathrm{ml})$ and $\mathrm{tBuOK}$ was added $(2.24 \mathrm{~g}, 20 \mathrm{mmol})$ prior to benzophenone $(3.64 \mathrm{~g}$, $20 \mathrm{mmol})$. The solution was refluxed for $4 \mathrm{~h}$. The resulting mixture was diluted with water $(50 \mathrm{ml})$ and extracted with EtOAc $(3 \times 100 \mathrm{ml})$. The organic layers were combined and dried $\left(\mathrm{MgSO}_{4}\right)$. Purification (flash chromatography EtOAc: PE 10:90) gave the pure ketone 9 as a solid $(2 \cdot 13 \mathrm{~g}, 60 \%)$.

Method B: To a solution of nitrile 10 (3 g, $20.5 \mathrm{mmol})$ in THF $(20 \mathrm{ml})$ was added a THF solution of BrMgEt freshly prepared $(31 \mathrm{ml}, 61.5 \mathrm{mmol}$, $2 \mathrm{~N}$ in THF), followed by addition of $\mathrm{CuBr}(60 \mathrm{mg})$. The mixture was refluxed $4 \mathrm{~h}$ under nitrogen then cooled. Water was added $(15 \mathrm{ml})$, followed by careful addition of $\mathrm{H}_{2} \mathrm{SO}_{4}(1 \mathrm{~N}, 50 \mathrm{ml})$. The mixture was refluxed for $1 \mathrm{~h}$ and then cooled. Neutralization with $\mathrm{NaOH}$ was followed with extraction with EtOAc $(3 \times 100 \mathrm{ml})$. The organic layer was dried $\left(\mathrm{MgSO}_{4}\right)$ and the solvent removed under reduced pressure. The ketone 9 was obtained as a solid (3.6 g, 98\%) with satisfactory purity for the next step.

${ }^{1} \mathrm{H}$ NMR $\left(300 \mathrm{MHz}, \mathrm{CDCl}_{3}\right) \delta \mathrm{ppm}: 1 \cdot 18(d, 6 \mathrm{H}$, $J=6.6 \mathrm{~Hz}), 3.0(s, 6 \mathrm{H}), 3.5(q, 1 \mathrm{H}, J=6.8 \mathrm{~Hz})$, $6.60(d, 2 \mathrm{H}, J=9.0 \mathrm{~Hz}), 7.9(d, 2 \mathrm{H}, J=9.0 \mathrm{~Hz})$; ${ }^{13} \mathrm{C}$ NMR $\left(75 \mathrm{MHz}, \mathrm{CDCl}_{3}\right) \delta \mathrm{ppm}: 19 \cdot 5,34 \cdot 1,39 \cdot 6$, $110 \cdot 6,123 \cdot 6,130 \cdot 3,153 \cdot 1,201 \cdot 9$.

\subsection{1-(4-Dimethylaminophenyl)-2-methyl- propan-1-one 13c}

Prepared as mentioned above from nitrile 10 (3 g, $20.5 \mathrm{mmol})$, THF $(20 \mathrm{ml})$ and a THF solution of BrMgiPr freshly prepared $(31 \mathrm{ml}, 61.5 \mathrm{mmol}, 2 \mathrm{~N}$ in THF) as a solid $(3.5 \mathrm{~g}, 90 \%) .{ }^{1} \mathrm{H}$ NMR $(300 \mathrm{MHz}$, $\left.\mathrm{CDCl}_{3}\right) \delta \mathrm{ppm}: 1.2(t, 3 \mathrm{H}, J=7 \cdot 3 \mathrm{~Hz}), 2.9(q, 2 \mathrm{H}, J=$ $7.3 \mathrm{~Hz}), 3.05(s, 6 \mathrm{H}), 6.65(d, 2 \mathrm{H}, J=9.2 \mathrm{~Hz}), 7.9$ $(d, 2 \mathrm{H}, J=9.2 \mathrm{~Hz}) ;{ }^{13} \mathrm{C}$ NMR $\left(75 \mathrm{MHz}, \mathrm{CDCl}_{3}\right) \delta$ ppm: $8 \cdot 8,30 \cdot 9,40 \cdot 0,110 \cdot 6,124 \cdot 6,130 \cdot 3,153 \cdot 3$, $199 \cdot 8$.

\subsection{2,2-Dibromo-1-(4-dimethylaminophenyl)- propan-1-one $\mathbf{1 1}$}

Ketone 9 (25 g, 0.14 mol) was dissolved in concentrated $\mathrm{H}_{2} \mathrm{SO}_{4}(150 \mathrm{ml})$ and bromine $(8 \mathrm{ml}, 0 \cdot 16 \mathrm{~mol})$ 
was added drop-wise while maintaining the temperature at $0^{\circ} \mathrm{C}$. After stirring $6 \mathrm{~h}$ the temperature was allowed to warm to room temperature and ice cold water was then added. The precipitate obtained was filtered off and washed with ice cold water to give the dibrominated compound 11 (42.2 g, 90\%) pure enough for the next step.

${ }^{1} \mathrm{H}$ NMR $\left(300 \mathrm{MHz}, \mathrm{CDCl}_{3}\right) \delta \mathrm{ppm}: 2 \cdot 65(s, 3 \mathrm{H})$, $3.05(s, 6 \mathrm{H}), 6.60(d, 2 \mathrm{H}, J=9.2 \mathrm{~Hz}), 8.3(d, 2 \mathrm{H}$, $J=9.2 \mathrm{~Hz}) ;{ }^{13} \mathrm{C}$ NMR $\left(75 \mathrm{MHz}, \mathrm{CDCl}_{3}\right) \delta \mathrm{ppm}$ : $38 \cdot 0,40 \cdot 0,58 \cdot 8,110 \cdot 0,118 \cdot 5,133 \cdot 8,153 \cdot 3,186 \cdot 1$.

\subsection{2-Bromo-1-(4-dimethylaminophenyl)- propan-1-one $\mathbf{1 2}$}

$11(30 \mathrm{~g}, 0.09 \mathrm{~mol})$ was dissolved in THF $(150 \mathrm{ml})$ and cooled to $0^{\circ} \mathrm{C}$. $(\mathrm{EtO})_{2} \mathrm{PH}=\mathrm{O}(13 \mathrm{ml}, 0.1 \mathrm{~mol})$ was then added followed by a solution of $\mathrm{NEt}_{3}$ $(14 \mathrm{ml}, 0.1 \mathrm{~mol})$ in THF $(80 \mathrm{ml})$. The temperature was allowed to warm to room temperature under stirring for $6 \mathrm{~h}$ and the resulting mixture concentrated under reduced pressure and hydrolysed by ice cold water $(300 \mathrm{ml})$. The resulting precipitate was filtered off and washed with ice cold water to afford the monobrominated compound $\mathbf{1 2}$ as a yellow solid (23 g, 90\%).

${ }^{1} \mathrm{H}$ NMR $\left(300 \mathrm{MHz}, \mathrm{CDCl}_{3}\right) \delta \mathrm{ppm}: 1 \cdot 2(d, 3 \mathrm{H}$, $J=6.6 \mathrm{~Hz}), 3.05(s, 6 \mathrm{H}), 5.2(q, 1 \mathrm{H}, J=6.6 \mathrm{~Hz})$, $6.6(d, 2 \mathrm{H}, J=9.2 \mathrm{~Hz}), 7.85(d, 2 \mathrm{H}, J=9.2 \mathrm{~Hz})$; ${ }^{13} \mathrm{C}$ NMR $\left(75 \mathrm{MHz}, \mathrm{CDCl}_{3}\right.$ ) $\delta \mathrm{ppm}: 20 \cdot 9,40 \cdot 4,42 \cdot 1$, $111 \cdot 2,121 \cdot 9,131 \cdot 5,154 \cdot 0,191 \cdot 6$.

\subsection{1-(4-Dimethylamino-phenyl)-2-fluoro- propan-1-one $\mathbf{1 3 b}$}

Crown ether 18C6 $(269 \mathrm{mg})$ and $\mathrm{KF}(1.8 \mathrm{~g}, 30 \mathrm{mmol})$ were dissolved in dry $\mathrm{CH}_{3} \mathrm{CN}(20 \mathrm{ml})$. The solution was stirred $30 \mathrm{~min}$. at $90^{\circ} \mathrm{C}$ prior to addition of bromoketone $12(15 \mathrm{mmol})$. The mixture was then stirred for $24 \mathrm{~h}$. After cooling ether was added $(50 \mathrm{ml})$ and the salts were removed by filtration. The organic layer was washed with water $(100 \mathrm{ml})$, dried and concentrated under reduced pressure. The crude material was purified (flash chromatography on silica, PE : EtOAc $90: 10)$ to give the fluoro compound $\mathbf{1 3 b}$ as a solid (16 g, 91\%).

${ }^{1} \mathrm{H}$ NMR $\left(300 \mathrm{MHz}, \mathrm{CDCl}_{3}\right) \delta \mathrm{ppm}: 1.65(d d, 3 \mathrm{H}$, $J=6.8,23.9 \mathrm{~Hz}), 3.05(s, 6 \mathrm{H}), 5.65(d q, 1 \mathrm{H}$, $J=6.8,49.9 \mathrm{~Hz}), 6.60(d, 2 \mathrm{H}, J=8.7 \mathrm{~Hz}), 7.9(d$, $2 \mathrm{H}, J=8.7 \mathrm{~Hz}) ;{ }^{13} \mathrm{C}$ NMR $\left(75 \mathrm{MHz}, \mathrm{CDCl}_{3}\right) \delta \mathrm{ppm}$ : $18.9(d, J=23 \cdot 1 \mathrm{~Hz}), 39.9,90 \cdot 5(d, J=178 \mathrm{~Hz})$,
$110 \cdot 7,121 \cdot 6,131 \cdot 2(d, J=3 \cdot 8 \mathrm{~Hz}), 153 \cdot 7,194 \cdot 4(d$, $J=18 \cdot 1 \mathrm{~Hz}$ ).

\subsection{5-(4-Dimethylaminophenyl)-2,4,4-trimethyl- 5-oxo-pent-2-enal 14c}

To a solution of $\mathrm{iPr}_{2} \mathrm{NH}$ (freshly distilled, $1.3 \mathrm{ml}$, $9 \mathrm{mmol})$ in THF $(20 \mathrm{ml})$ cooled to $-20^{\circ} \mathrm{C}$ was added drop wise $\mathrm{nBuLi}(5.7 \mathrm{ml}, 1.6 \mathrm{M}$ in hexane, $9 \mathrm{mmol})$. After 30 min stirring, temperature was cooled to $-78^{\circ} \mathrm{C}$ and ketone $13 \mathrm{c}(1.44 \mathrm{~g}, 7.5 \mathrm{mmol})$ in THF $(10 \mathrm{ml})$ was added. After stirring $1.5 \mathrm{~h}$ at $-78^{\circ} \mathrm{C}$, $\mathrm{MeOCH}=\mathrm{C}(\mathrm{Me}) \mathrm{CHO}(0.86 \mathrm{~g}, 7.5 \mathrm{mmol})$ in THF $(5 \mathrm{ml})$ was added. The temperature was brought to room temperature overnight. A saturated $\mathrm{NH}_{4} \mathrm{Cl}$ solution was added $(100 \mathrm{ml})$ and the resulting mixture extracted with ether $(3 \times 100 \mathrm{ml})$. The combined organic layers were dried $\left(\mathrm{MgSO}_{4}\right)$ and concentrated under reduced pressure. Purification (flash chromatography on silica, EtOAc: PE $30: 70)$ gave $\mathbf{1 4 c}$ as a yellow oil ( $1.5 \mathrm{~g}, 77 \%)$.

${ }^{1} \mathrm{H}$ NMR $\left(300 \mathrm{MHz}, \mathrm{CDCl}_{3}\right) \delta \mathrm{ppm}: 1.45(d, 3 \mathrm{H}$, $J=1.3 \mathrm{~Hz}) ; 1.51(s, 6 \mathrm{H}), 3.1(s, 6 \mathrm{H}), 6.5(d, 2 \mathrm{H}$, $J=9.2 \mathrm{~Hz}), 6.9(d, 2 \mathrm{H}, J=1.3 \mathrm{~Hz}), 7.8(d, 2 \mathrm{H}$, $J=9 \cdot 2 \mathrm{~Hz}), 9 \cdot 4(s, 1 \mathrm{H}) ;{ }^{13} \mathrm{C}$ NMR $\left(75 \mathrm{MHz}, \mathrm{CDCl}_{3}\right)$ $\delta$ ppm: 9.4, 27.2, 40.0, 48.0, 110.2, 121.5, 131.6, $139 \cdot 5,153 \cdot 0,160 \cdot 1,195 \cdot 2,199 \cdot 6$.

\subsection{5-(4-Dimethylaminophenyl)-4-fluoro-2,4- dimethyl-5-oxo-pent-2-enal 14b}

Prepared as $14 \mathbf{c}$ from $13 \mathbf{b}(7.5 \mathrm{mmol}$ in $10 \mathrm{ml}$ THF), LDA $\left(\mathrm{iPr}_{2} \mathrm{NH}, 1.3 \mathrm{ml}, 9 \mathrm{mmol} ; n \mathrm{BuLi} \quad(5.7 \mathrm{ml}\right.$, $1.6 \mathrm{M}$ in hexane, $9 \mathrm{mmol}$ in $20 \mathrm{ml} \mathrm{THF}$ ) and $\mathrm{MeOCH}=\mathrm{C}(\mathrm{Me}) \mathrm{CHO}(0.86 \mathrm{~g}, 7.5 \mathrm{mmol}$, in $5 \mathrm{ml}$ THF) as a yellow oil ( $1.62 \mathrm{~g}, 82 \%)$.

${ }^{1} \mathrm{H}$ NMR $\left(300 \mathrm{MHz}, \mathrm{CDCl}_{3}\right) \delta \mathrm{ppm}: 1.85(d, 3 \mathrm{H}$, $J=22.5 \mathrm{~Hz}), 1.85(t, 3 \mathrm{H}, J=1.5 \mathrm{~Hz}), 3.05(s, 6 \mathrm{H})$, $6.60(d d, 1 \mathrm{H}, J=1.5,22.0 \mathrm{~Hz}), 6.65(d, 2 \mathrm{H}$, $J=9.2 \mathrm{~Hz}), 7.9(d d, 2 \mathrm{H}, J=1.3,8.7 \mathrm{~Hz}), 9.4(s$, $1 \mathrm{H}) ;{ }^{13} \mathrm{C}$ NMR $\left(75 \mathrm{MHz}, \mathrm{CDCl}_{3}\right) \delta \mathrm{ppm}: 9.5(d$, $J=4.4 \mathrm{~Hz}), 23.7(d, J=24.7 \mathrm{~Hz}), 39.9,99.9(d$, $J=183.3 \mathrm{~Hz}), 110.5,120.9(d, J=3.8 \mathrm{~Hz}), 132.5$ $(d, J=7.1 \mathrm{~Hz}), 139.4(d, J=3.8 \mathrm{~Hz}), 150.7(d$, $J=24 \cdot 7 \mathrm{~Hz}), 153 \cdot 7,193 \cdot 0(d, J=24 \cdot 2 \mathrm{~Hz}), 194 \cdot 3$.

\subsection{7-(4-Dimethylaminophenyl)-4,6,6-trimethyl- 7-oxo-hepta-2,4-dienoic acid ethyl ester $\mathbf{1 5 c}$}

To a solution of aldehyde $14 \mathrm{c}(1.3 \mathrm{~g}, 5 \mathrm{mmol})$ in benzene $(15 \mathrm{ml})$ was added $\mathrm{Ph}_{3} \mathrm{P}=\mathrm{CHCOOEt}$ 
$(1.73 \mathrm{~g}, 5 \mathrm{mmol})$. After $4 \mathrm{~h}$ reflux, benzene was removed under reduced pressure and the crude oil purified (flash chromatography EtOAc: PE 10:90) to give a yellow oil. Recrystallisation from $\mathrm{CH}_{2} \mathrm{Cl}_{2} /$ $\mathrm{PE}$ gave the ester as a colourless oil $(1.44 \mathrm{~g}, 85 \%)$. ${ }^{1} \mathrm{H}$ NMR $\left(300 \mathrm{MHz}, \mathrm{CDCl}_{3}\right) \delta \mathrm{ppm}: 1.35(t, 3 \mathrm{H}$, $J=7.1 \mathrm{~Hz}), 1.40(s, 3 \mathrm{H}), 1.45(d, 3 \mathrm{H}, J=0.7 \mathrm{~Hz})$, $3 \cdot 1(s, 6 \mathrm{H}), 4 \cdot 2(q, 1 \mathrm{H}, J=7 \cdot 1 \mathrm{~Hz}), 5 \cdot 7(d, 1 \mathrm{H}$, $J=15.4 \mathrm{~Hz}), 6.60(d, 2 \mathrm{H}, J=9.2 \mathrm{~Hz}), 6.3(s, 1 \mathrm{H})$, $7.3(d d, \quad 1 \mathrm{H}, \quad J=0.7, \quad 15.4 \mathrm{~Hz}), \quad 7.9 \quad(d, 2 \mathrm{H}$, $J=9.2 \mathrm{~Hz}) ;{ }^{13} \mathrm{C}$ NMR $\left(75 \mathrm{MHz}, \mathrm{CDCl}_{3}\right) \delta \mathrm{ppm}$ : $12 \cdot 5,14 \cdot 3,28 \cdot 0,39 \cdot 8,47 \cdot 8,60 \cdot 1,110 \cdot 1,116 \cdot 4,121 \cdot 9$, $131 \cdot 8,133 \cdot 8,147 \cdot 9,149 \cdot 5,152 \cdot 7,167 \cdot 3,201 \cdot 2$.

\subsection{7-(4-Dimethylaminophenyl)-6-fluoro-}

4,6-dimethyl-7-oxo-hepta-2,4-dienoic acid ethyl ester $\mathbf{1 5 b}$

Prepared as 15c from aldehyde 14b (1.31 g, $5 \mathrm{mmol}), \mathrm{Ph}_{3} \mathrm{P}=$ CHCOOEt $(1.73 \mathrm{~g}, 5 \mathrm{mmol})$ and benzene $(15 \mathrm{ml})$ as a colourless oil $(1.42 \mathrm{~g}, 85 \%) .{ }^{1} \mathrm{H}$ NMR $\left(300 \mathrm{MHz}, \mathrm{CDCl}_{3}\right) \delta \mathrm{ppm}: 1.28(t, 3 \mathrm{H}$, $J=7.1 \mathrm{~Hz}), 1.75(d, 3 \mathrm{H}, J=22.7 \mathrm{~Hz}), 1.85(t, 3 \mathrm{H}$, $J=1.25 \mathrm{~Hz}), 3.05(s, 6 \mathrm{H}), 4.20(d, 2 \mathrm{H}, J=7.1 \mathrm{~Hz})$, $5.8(d, 1 \mathrm{H}, J=15.7 \mathrm{~Hz}), 6.27(d, 1 \mathrm{H}, J=20.9 \mathrm{~Hz})$, $6.60(d, 2 \mathrm{H}, J=9.0 \mathrm{~Hz}), 7.3(d, 1 \mathrm{H}, J=15.7 \mathrm{~Hz})$, $7.95(d d, 2 \mathrm{H}, J=1 \cdot 1,9 \cdot 1) ;{ }^{13} \mathrm{C}$ NMR $(75 \mathrm{MHz}$, $\left.\mathrm{CDCl}_{3}\right) \delta \mathrm{ppm}: 12 \cdot 7(d, J=3.3 \mathrm{~Hz}), 14 \cdot 2,24.4(d$, $J=25.2 \mathrm{~Hz}), 39 \cdot 7,60 \cdot 3,99 \cdot 1 \quad(d, J=179.5 \mathrm{~Hz})$, $110 \cdot 4,118 \cdot 5,120 \cdot 8(\mathrm{~d}, J=3.3 \mathrm{~Hz}), 132.4(d, J=$ $5.5 \mathrm{~Hz}), 135.2(d, J=6.6 \mathrm{~Hz}), 139 \cdot 1(d, J=23.7 \mathrm{~Hz})$, $148 \cdot 3,153 \cdot 5,166 \cdot 7,193 \cdot 9(d, J=24 \cdot 7 \mathrm{~Hz})$.

\subsection{7-(4-Dimethylaminophenyl)-4, 6,6-trimethyl- 7-oxo-hepta-2,4-dienoic acid $\mathbf{1 6 c}$}

To a solution of ester $15 \mathrm{c}(930 \mathrm{mg}, 2.97 \mathrm{mmol})$ in THF : $\mathrm{MeOH}(5: 1,12 \mathrm{ml})$ was added an aqueous solution of $\mathrm{LiOH}(2.5 \mathrm{M}, 2 \mathrm{ml})$. After stirring overnight at ambient temperature, the mixture was acidified to $\mathrm{pH} 1$ with $\mathrm{HCl}(6 \mathrm{~N})$. The mixture was then diluted with $\mathrm{H}_{2} \mathrm{O}(50 \mathrm{ml})$ and saturated with $\mathrm{NaCl}$ and extracted with EtOAc $(6 \times 50 \mathrm{ml})$ until no more acid was found in the aqueous layer. The combined organic layers are dried $\left(\mathrm{MgSO}_{4}\right)$ and concentrated to give the crude acid. Minimum $\mathrm{CH}_{2} \mathrm{Cl}_{2}$ was then added to dissolve the acid and $100 \mathrm{ml}$ of EP was added to obtain the acid as a white precipitate. After removal of the supernatant, the acid is obtained as a white solid. This purification was repeated twice and give the acid $(850 \mathrm{mg}, 95 \%)$ pure enough for the next step. ${ }^{1} \mathrm{H}$ NMR $(300 \mathrm{MHz}$, $\left.\mathrm{CDCl}_{3}\right) \delta \mathrm{ppm}: 1.40(s, 6 \mathrm{H}), 1.45(s, 3 \mathrm{H}), 3.1(s$, $6 \mathrm{H}), 5.7(d, 1 \mathrm{H}, J=15.4 \mathrm{~Hz}), 6.4(s, 1 \mathrm{H}), 6.60(d$, $2 \mathrm{H}, J=9.2 \mathrm{~Hz}), 7.4(d, 1 \mathrm{H}, J=15.4 \mathrm{~Hz}), 7.9(d$, $2 \mathrm{H}, J=9.0 \mathrm{~Hz}$ ).

\subsection{7-(4-Dimethylaminophenyl)-4, 6, 6-trimethyl- 7-oxo-hepta-2,4-dienoic acid $\mathbf{1 6 b}$}

Prepared as $\mathbf{1 6 c}$ from ester $\mathbf{1 5 b}(1.13 \mathrm{~g}, 3.4 \mathrm{mmol})$, THF : $\mathrm{MeOH}(5: 1,46.4 \mathrm{ml})$ and $\mathrm{LiOH}(2.5 \mathrm{M}$ aq., $7.7 \mathrm{ml})$ as a white solid $(986 \mathrm{mg}, 95 \%)$.

\subsection{7-(4-Dimethylaminophenyl)-4, 6, 6-trimethyl- 7-oxo-hepta-2,4-dienoic acid (2-aminophenyl)- amide 6c}

To a solution of acid $16 \mathrm{c}(157 \mathrm{mg} ; 0.52 \mathrm{mmol})$ in dry THF $(5 \mathrm{ml})$ was added 1,2-diaminobenzene (340 mg, $3.12 \mathrm{~mol}$ ) and EDC (145 mg, $0.68 \mathrm{mmol}$ ). After stirring overnight, the solution was concentrated under vacuum. EtOAc was added $(50 \mathrm{ml})$ and the resulting organic layer washed with $\mathrm{H}_{2} \mathrm{O}(30 \mathrm{ml})$ and then twice with aqueous $1 \mathrm{~N} \mathrm{NaOH}(20 \mathrm{ml})$. The organic layer was dried $\left(\mathrm{MgSO}_{4}\right)$ and solvents removed under vacuum. The resulting solid was purified (flash chromatography EtOAc:PE $60: 40$ ) to give the benzamide $\mathbf{6 c}$ as a pale yellow powder (144 mg, 71\%, mp: $\left.136-140^{\circ} \mathrm{C}\right) ;{ }^{1} \mathrm{H}$ NMR $(300 \mathrm{MHz}$, $\left.\mathrm{CDCl}_{3}\right) \delta \mathrm{ppm}: 1 \cdot 40(s, 6 \mathrm{H}), 1 \cdot 5(s, 3 \mathrm{H}), 3 \cdot 0(s, 6 \mathrm{H})$, $3.9(s, 2 \mathrm{H}), 5.8(d, 1 \mathrm{H}, J=15.4 \mathrm{~Hz}), 6 \cdot 3(s, 1 \mathrm{H})$, $6.60(d, 2 \mathrm{H}, J=9.0 \mathrm{~Hz}), 6.8(d, 1 \mathrm{H}, J=7.5 \mathrm{~Hz}), 7 \cdot 0$ $(t, 1 \mathrm{H}, J=7.5 \mathrm{~Hz}), 7.2(d, 1 \mathrm{H}, J=7.5 \mathrm{~Hz}), 7.4(d$, $1 \mathrm{H}, J=15.4 \mathrm{~Hz}), 7.5(s, 1 \mathrm{H}), 7.9(d, 2 \mathrm{H}, J=$ $9.0 \mathrm{~Hz}) ;{ }^{13} \mathrm{C}$ NMR $\left(75 \mathrm{MHz}, \mathrm{CDCl}_{3}\right) \delta \mathrm{ppm}: 12 \cdot 8$, $28 \cdot 0,39.9,47 \cdot 9,110 \cdot 1,118 \cdot 1,118 \cdot 2,119.5,121.9$, $124.5,125 \cdot 0,127 \cdot 0,131.9,133.6,140.7,147 \cdot 3$, $147 \cdot 6,152 \cdot 7,164 \cdot 7,201 \cdot 6$.

\subsection{7-(4-Dimethylaminophenyl)-6-fluoro-4,6- dimethyl-7-oxo-hepta-2,4-dienoic acid (2-aminophenyl) amide $\mathbf{6 b}$}

Prepared as 6c from acid 16b (159 $\mathrm{mg}, 0.52 \mathrm{mmol})$, THF (5 ml), 1,2-diaminobenzene (340 mg, $3.12 \mathrm{mmol}$ ) and EDC (145 mg, $0.68 \mathrm{mmol})$ as a pale yellow solid $(150 \mathrm{mg}, 73 \%) .{ }^{1} \mathrm{H}$ NMR $\left(300 \mathrm{MHz}, \mathrm{CDCl}_{3}\right)$ $\delta$ ppm: $1.7(m, 6 \mathrm{H}), 3.0(s, 6 \mathrm{H}), 6.0(d, 2 \mathrm{H}, J=$ $8.8 \mathrm{~Hz}), 6.04(d, 1 \mathrm{H}, J=15.3 \mathrm{~Hz}), 6.3(d, 1 \mathrm{H}$, $J=20.3 \mathrm{~Hz}), 6.8(m, 2 \mathrm{H}), 7.0(t, 1 \mathrm{H}, J=7.2 \mathrm{~Hz})$, $7 \cdot 25-7.35(m, 3 \mathrm{H}), 8.0(d, 2 \mathrm{H}, J=8.8 \mathrm{~Hz})$; HRMS 
ESI: $\left(\mathrm{C}_{23} \mathrm{H}_{26} \mathrm{~N}_{3} \mathrm{O}_{2} \mathrm{~F}\right) \mathrm{M}^{+}$calcd: $395 \cdot 20091$, found: $395 \cdot 2003$.

\subsection{7-(4-Dimethylaminophenyl)-4, 6,6-trimethyl- 7-oxo-hepta-2,4-dienoic acid hydroxyamide 5c}

To a solution of carboxylic acid (188 $\mathrm{mg}, 0.625 \mathrm{mmol})$ in DMF $(2 \mathrm{ml})$ were added TBTU $(300 \mathrm{mg}$, $0.937 \mathrm{mmol})$ and $\mathrm{NEt}_{3}(0.17 \mathrm{ml}, 1.25 \mathrm{mmol})$. After $2 \mathrm{~h} \mathrm{NH}$-OTHP was added $(110 \mathrm{mg}, 0.937 \mathrm{mmol})$ and stirring continued overnight. The resulting solution was neutralized with $\mathrm{NaHCO}_{3}$ (saturated) and extracted with EtOAc $(3 \times 50 \mathrm{ml})$. The organic layers were combined and dried $\left(\mathrm{MgSO}_{4}\right)$, and the solvent removed under reduced pressure. The protected O-THP derivative was purified (flash chromatography on silica, EP : EtOAc $60: 40)$ and dissolved in $\mathrm{MeOH}(5 \mathrm{ml})$. Amberlyst was then added $(150 \mathrm{mg})$ and the mixture stirred at ambient temperature until the starting material is completely consumed (for 3 to $6 \mathrm{~h}$ ). The resin is filtered off and $\mathrm{MeOH}$ removed under reduced pressure. Purification (flash chromatography on silica, EtOAc) gave de hydroxamate as a pale pink solid (123 mg, 62\%). ${ }^{1} \mathrm{H}$ NMR $(300 \mathrm{MHz}$, $\left.\mathrm{CD}_{3} \mathrm{OD}\right) \delta \mathrm{ppm}: 1.35(\mathrm{~m}, 9 \mathrm{H}), 3 \cdot 1(\mathrm{~s}, 6 \mathrm{H}), 5 \cdot 65(d$, $1 \mathrm{H}, J=15 \cdot 2 \mathrm{~Hz}), 6 \cdot 35(s, 1 \mathrm{H}), 7 \cdot 2(m, 3 \mathrm{H}), 8 \cdot 0(d$, $2 \mathrm{H}, \quad J=9.0 \mathrm{~Hz}) ;{ }^{13} \mathrm{C}$ NMR $\left(75 \mathrm{MHz}, \quad \mathrm{CD}_{3} \mathrm{OD}\right)$ $\delta$ ppm: 13.4, 28.5, 45.1, 117.0, 118.6, 132.7, 133.4, $136 \cdot 0,147 \cdot 0,147 \cdot 3,149 \cdot 9,166 \cdot 9,204 \cdot 0$.

\subsection{7-(4-Dimethylaminophenyl)-6-fluoro-4,6- dimethyl-7-oxo-hepta-2,4-dienoic acid hydroxyamide $\mathbf{5 b}$}

Prepared as 5c from 16b (191 mg, $0.625 \mathrm{mmol})$, DMF (2 ml), TBTU (300 mg, $0.937 \mathrm{mmol})$ and $\mathrm{NEt}_{3}$ $(0.17 \mathrm{ml}, 1.25 \mathrm{mmol})$ and $\mathrm{NH}_{2}$-OTHP $(110 \mathrm{mg}$, $0.937 \mathrm{mmol})$ as a light red solid $(94 \mathrm{mg}, 47 \%) .{ }^{1} \mathrm{H}$ NMR (300 MHz, $\left.\mathrm{CD}_{3} \mathrm{OD}\right) \delta \mathrm{ppm}: 1 \cdot 70(m, 6 \mathrm{H}), 3 \cdot 0$ $(s, 6 \mathrm{H}), 5.9(d, 1 \mathrm{H}, J=15.4 \mathrm{~Hz}), 6.3(d, 1 \mathrm{H}, J=$ $19.6 \mathrm{~Hz}), 6.66(d, 2 \mathrm{H}, J=8.8 \mathrm{~Hz}), 7.2(d, 1 \mathrm{H}$, $J=15.5 \mathrm{~Hz}), 7.8(d, 2 \mathrm{H}, J=8.8 \mathrm{~Hz}) ;{ }^{13} \mathrm{C}$ NMR $\left(75 \mathrm{MHz}, \mathrm{CD}_{3} \mathrm{OD}\right) \delta \mathrm{ppm}: 13 \cdot 1(d, J=3 \cdot 3 \mathrm{~Hz}), 25 \cdot 2$ $(d, J=25 \cdot 2 \mathrm{~Hz}), 40 \cdot 0,99 \cdot 3(d, J=178 \mathrm{~Hz}), 111 \cdot 5$, $119.0,121.5,133.5(d, J=4.9 \mathrm{~Hz}), 137.1(d, J=$ $7 \cdot 1 \mathrm{~Hz}), 139 \cdot 1(d, J=23 \cdot 6 \mathrm{~Hz}), 145 \cdot 5,155 \cdot 3,166 \cdot 1$, $196 \cdot 2(d, J=23 \cdot 6 \mathrm{~Hz})$.

\subsection{Cell culture}

The NCI-H661 non-small cell lung cancer cells were grown in RPMI 1640 plus $10 \%$ fetal calf serum (InVitrogen) at $37^{\circ} \mathrm{C}$ and under $5 \% \mathrm{CO}_{2}$.

\subsection{Cell proliferation}

The Cell Proliferation Kit II (XTT; Roche) was used to assess cell proliferation. This assay is based on the cleavage of XTT by metabolic active cells resulting in the production of an orange formazan dye that is quantified by spectrophotometry. Assays were carried out essentially as described by the manufacturer. Briefly, $4 \times 10^{3}$ cells/well were plated in $100 \mu \mathrm{l}$ of media in a 96-well plate. Cells were grown for $24 \mathrm{~h}$ before adding the compound at the indicated concentration. After $48 \mathrm{~h}$ treatment, $50 \mu \mathrm{l}$ of the XTT labelling mixture were added per well. Cells were further incubated for additional $4 \mathrm{~h}$ at $37^{\circ} \mathrm{C}$ before reading the absorbance at $480 \mathrm{~nm}$.

\subsection{Western blot analysis}

$5 \times 10^{5}$ cells were treated with the compounds for $5.30 \mathrm{~h}$ for histone $\mathrm{H} 4$ and tubulin acetylation analysis. Cells were lysed in $200 \mu \mathrm{l}$ of the electrophoresis loading buffer from Laemmli and sonicated. Protein lysates were resolved by SDS-PAGE, followed by Western blot. Primary antibodies were rabbit polyclonal anti-acetylated histone $\mathrm{H} 4$ antibody (1/500; Upstate) or mouse monoclonal anti- $\alpha$-tubulin antibody (1/2000; Sigma). HRP-conjugated anti-mouse and anti-rabbit secondary antibodies (Amersham) were used at 1/5000 dilution. Detection was performed with ECL (Perkin Elmer).

\section{Results and discussion}

A general route was thus designed in a convergent way and allowing the potential introduction of several functional groups in the alpha position of the ketone of trichostatic acid. A methyl group was selected to compare the rigid compound 5a and 6a with the flexible derivatives $\mathbf{5 b}, \mathbf{c}$ and $\mathbf{6 b}, \mathbf{c}$ (figure 2). Substitution of the hydrogen in position 6 was also envisioned with an atom not increasing the steric hindrance around the ketone. The fluorine atom was selected, having an equivalent atom radius compared to the hydrogen but introducing higher electronegativity. Some fluorinated compounds were described as HDACi, ${ }^{21,22}$ but fluorinated TSA was not described. Benzamide derivatives like MS-275, although weaker zinc ligands than the hydroxamic acids, generally lead to bioactive molecules and possess higher stability in biological environments. In this respect we prepared both hydroxamic acids and benzamide versions of the target structures. 


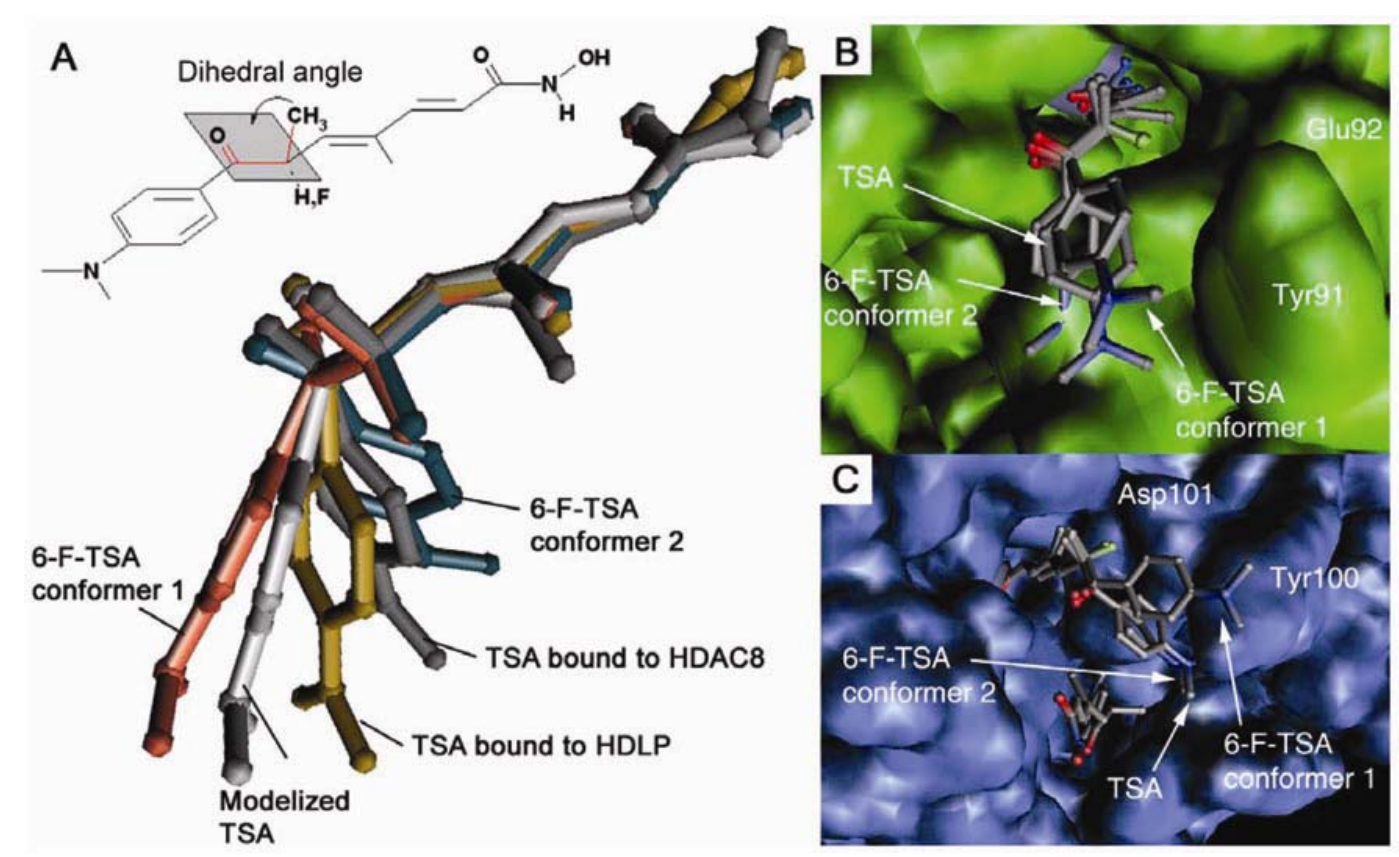

Figure 3. (A) Crystallographic structures of TSA bound to HDAC8 and HDLP, compared to modelized TSA and the two stable modelized conformers $\mathrm{C} 1$ and $\mathrm{C} 2$ of 6-Fluoro-TSA. (B) Docking of $\mathrm{C} 1$ and $\mathrm{C} 2$ in HDLP. (C) Docking of $\mathrm{C} 1$ and $\mathrm{C} 2$ in HDAC8.

Molecular modelling of the fluoro hydroxamate 5b was performed at the AM1 level. Validation of the method was made by modelling TSA and superimposition with the described structures of $\mathrm{TSA}^{23,24}$ (figure 3A) based on the overlapping of the hydroxamic acid group, alignment of the butadiene chain, and matching the two methyl groups and the carbonyl function. In trichostatic acid, the four atoms of the propanone system $\left(\mathrm{Ar}-\mathrm{C}=\mathrm{O}-\mathrm{C}-\mathrm{CH}_{3}\right)$ define a dihedral angle (figure $3 \mathrm{~A}$, top). In the several published crystallized HDACs with TSA bound, this dihedral angle is varying to accommodate the observed small differences in HDLP or HDAC8 conformations. We compared these differences with modelled TSA and 5b. AM1 modelled TSA (figure $3 \mathrm{~A})$ showed the highest dihedral angle. Interestingly, analogue $\mathbf{5 b}$ produced two stable conformers C1 $(-63.107 \mathrm{kcal} / \mathrm{mol})$ and C2 $(-63.348 \mathrm{kcal} / \mathrm{mol})$. In conformer $\mathrm{C} 1$, the dihedral angle increased probably in order to manage the electronic repulsions between the fluorine atom and the aromatic ring. This resulted in an aromatic ring plane positioned between the methyl group and the fluorine atom of carbon 6 . The dihedral angle decreased in the slightly more stable conformer $\mathrm{C} 2$, with the aromatic ring plane positioned between the fluorine atom and the butadiene chain. The docking of the two conformers $\mathrm{C} 1$ and $\mathrm{C} 2$ of compound $\mathbf{5 b}$ was investigated with the known X-ray structure of TSA (figure 3B, C respectively). In the case of TSA bound to HDLP, fluorinated conformer $\mathrm{C} 1$ was found more adequate while $\mathrm{C} 2$ produced interactions of the dimethylamino group with the surface of the protein. In the case of TSA bound to HDAC 8, interactions with Tyr100 were found higher for conformer $\mathrm{C} 1$. Thus conformer $\mathrm{C} 2$ appeared more adequate for comparison of fluorinated TSA bound to HDAC8. As X-ray crystallographic data with benzamide derivatives are still missing, modelling of the benzamide versions was not investigated.

Our synthetic strategy relied on the alkylation of convenient propiophenones by methoxymethacrolein, leading to intermediate precursor of pentadienoic acid. These acids were then converted to hydroxamic acids $\mathbf{5}$ or to benzamide derivatives $\mathbf{6}$. Propiophenones 13 were prepared from the corresponding derivatives 7 or $\mathbf{1 0}$ (scheme 1). In a first route, the aldehyde 7 was alkylated (EtMgBr, THF) to give alcohol 8 that under Oppenhauer oxidation gave the key ketone 9. A more convergent route was then implemented from the nitrile 10. Direct preparation of ketone 9 was obtained by alkylation of compound 10 with EtMgBr under copper catalysis. ${ }^{25}$ The same protocol allowed the preparation of ketone 
13c. Direct fluorination of compound 9 was not possible. A two-step strategy was implemented based on the monobromination of 9 and subsequent nucleophilic displacement by a fluorine atom. ${ }^{26}$ Unfortunately, bromination of 9 afforded exclusively in high yields the dibromo derivative $11{ }^{27}$ According to Diwu and Liu, mono debromination by diethylphophite afforded $12 .{ }^{28}$ The nucleophilic substitution under phase transfer catalysis finally gave the desired fluoro derivative 13b. Deprotonation of compounds $13 \mathrm{~b}, \mathrm{c}\left(\mathrm{LDA},-78^{\circ} \mathrm{C}\right)$ and ketolisation with methoxymethacrolein, followed by acidic work-up, gave propenal derivatives $14 \mathbf{b}, \mathbf{c}$ (scheme 2 ). The aldehydes $14 \mathbf{b}, \mathbf{c}$ were then converted to the conjugated trans esters $\mathbf{1 5 b}, \mathbf{c}$ by a Wittig elongation. Subsequent hydrolysis of the ester group gave the acids 16b,c. Hydroxamic acid derivatives 5b,c were obtained under TBTU coupling conditions between acids $16 \mathbf{b}, \mathbf{c}$ and the O-tetrahydropyranyl (OTHP) ether of hydroxylamine, followed by acidic hydrolysis of the intermediate O-THP ether of the hydroxamic acids. The benzamides $\mathbf{6 b}, \mathbf{c}$ were prepared under EDC coupling conditions between acids $16 \mathrm{~b}, \mathrm{c}$ and the 1,2-diaminobenzene.

New derivatives were tested for their antiproliferative activity against H661 human non-small cell lung cancer cells. ${ }^{20}$ After $48 \mathrm{~h}$ treatment (figure 4), $\mathrm{IC}_{50}$ were determined for $50 \%$ inhibition and were compared to those of SAHA, TSA and the reported
HDACi 5a and 6a (table 1). Compounds 5c and 6c were found inactive at the highest tested concentrations $(25 \mu \mathrm{M})$, probably because they cannot fit in

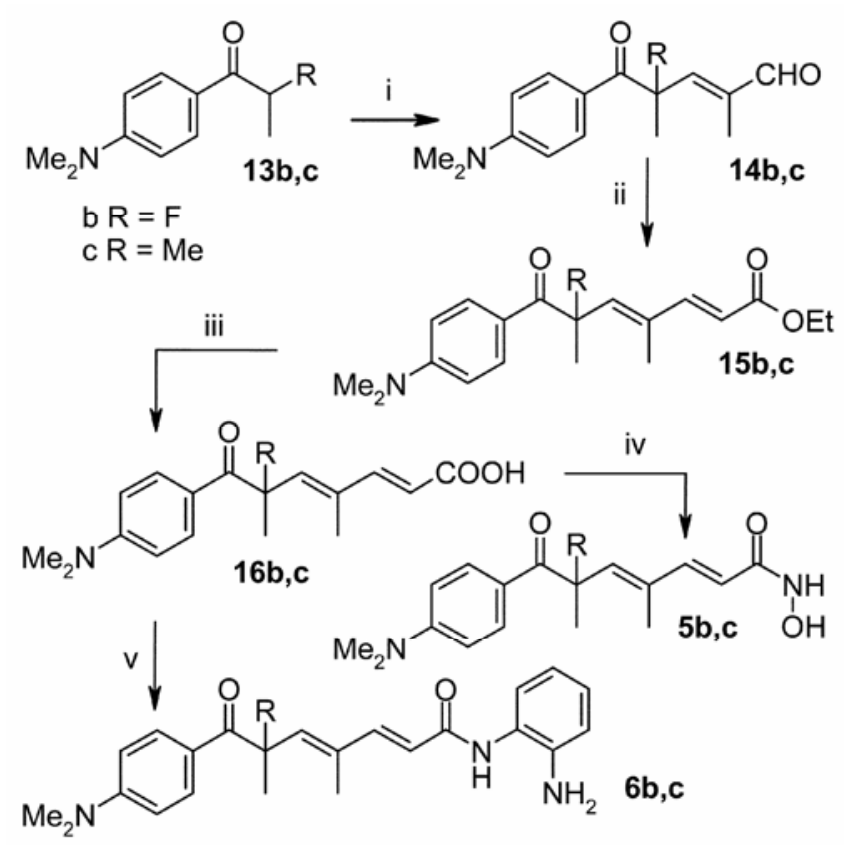

Scheme 2. (i) $\mathrm{LDA}, \mathrm{THF},-78^{\circ} \mathrm{C}, \mathrm{MeOCH}=\mathrm{C}(\mathrm{Me})$ $\mathrm{CHO}, 77-82 \%$; (ii) $\mathrm{Ph}_{3} \mathrm{P}=\mathrm{CHCOOEt}$, toluene, $85 \%$; (iii) $\mathrm{LiOH}, \mathrm{MeOH}, 95 \%$; (iv) (a) $\mathrm{H}_{2} \mathrm{~N}-\mathrm{OTHP}, \mathrm{TBTU}, \mathrm{DMF}$, $\mathrm{NEt}_{3}$; (b) $\mathrm{CSA}, \mathrm{CH}_{2} \mathrm{Cl}_{2}, \mathrm{MeOH}, 47-62 \%(\mathrm{a}+\mathrm{b})$; (v) $\mathrm{H}_{2} \mathrm{~N}-\mathrm{Ph}-\mathrm{NH}_{2}$, EDC, THF, 71-73\%.

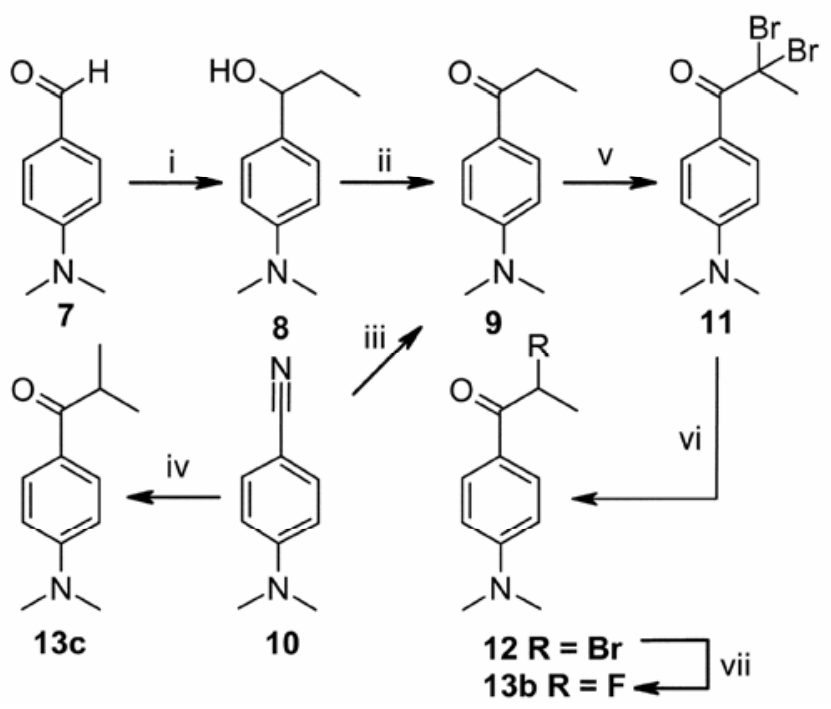

Scheme 1. (i) THF, EtMgBr, 98\%; (ii) tBuOK, benzophenone, 60\%; (iii) THF, EtMgBr, $\mathrm{CuBr}, 90 \%$; (iv) THF, iPrMgBr, $\mathrm{CuBr}, 90 \%$; (v) $\mathrm{H}_{2} \mathrm{SO}_{4}, \mathrm{Br}_{2}, 100 \%$; (vi) (EtO) ${ }_{2} \mathrm{POH}, \mathrm{NEt}_{3}, \mathrm{THF}, 96 \%$; (vii) $\mathrm{KF}, 18-\mathrm{C}-6, \mathrm{CH}_{3} \mathrm{CN}$, $95 \%$.

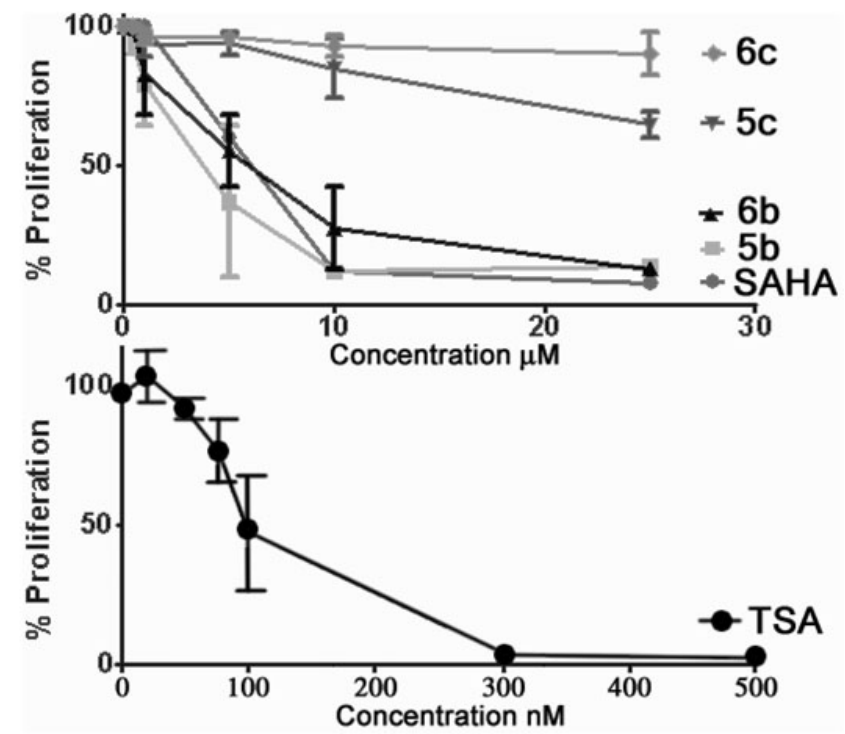

Figure 4. Antiproliferative activity of the indicated compounds after $48 \mathrm{~h}$ treatment of NCI-H661 cells. Two independent experiments were done in triplicate. Standard deviation is indicated. 
the entry pocket of the active site. This result is explained by the comparison of the indanone derivatives $5 \mathbf{a}$ and $6 \mathbf{a}$ with $5 \mathbf{c}$ and $\mathbf{6 c}$.

The indanone moiety generated a contraction ${ }^{20}$ that compensated for the steric hindrance of the methylene bridge. This is not possible for methylated derivatives $\mathbf{5 c}$ and $\mathbf{6 c}$, due to the free rotation. The fluorinated derivatives $\mathbf{5 b}$ and $\mathbf{6 b}$ were found active with respective $\mathrm{ICs}_{50}$ of 4 and $6 \mu \mathrm{M}$, equivalent to SAHA (figure 4), and 40 fold less active than TSA in the NCI-H661 lung cancer cell line. Only HDACi activity of the most active compound $\mathbf{5 b}$ was evaluated and compared to TSA. A $5 \mu \mathrm{M}$ concentration of compound $\mathbf{5 b}$ gave similar inhibition of HDAC than

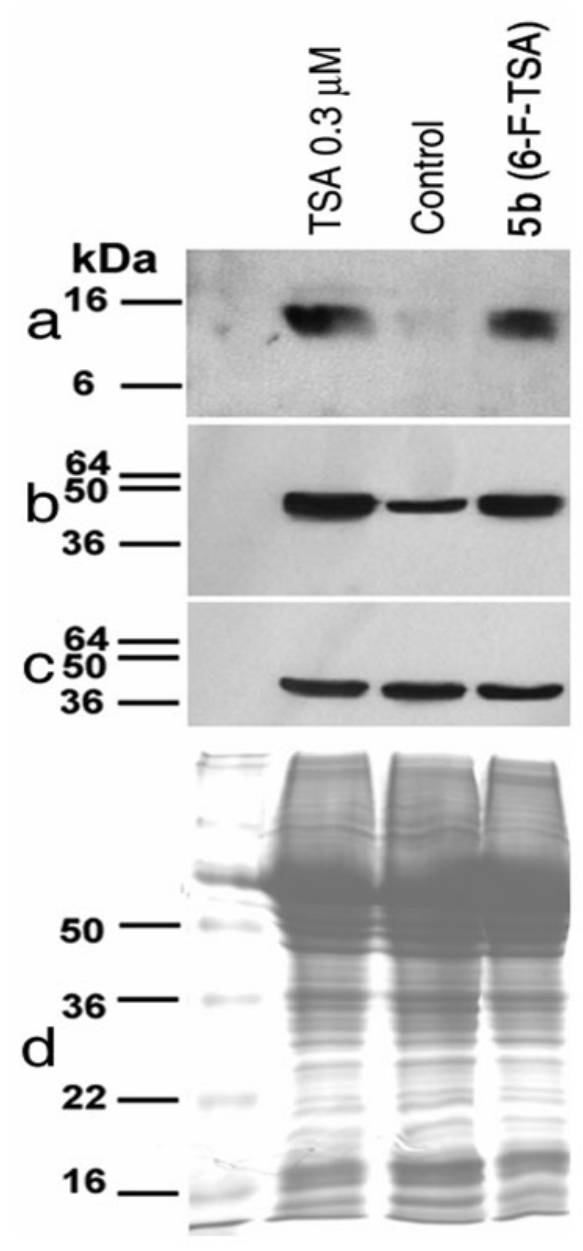

Figure 5. Analysis of histone $\mathrm{H} 4$ and tubulin acetylation. NCI-H661 cells were treated for $5 \mathrm{~h} 30 \mathrm{~min}$ with TSA $(0 \cdot 3 \mu \mathrm{M})$ and 6-Fluoro-TSA $5 \mathbf{b}(5 \mu \mathrm{M})$. Control is untreated cells. Western blots are representative of three independent experiments. Molecular weights are indicated in $\mathrm{KDa}$ on the left. (a) acetylated histone $\mathrm{H} 4$; (b) acetylated tubulin; (c) $\alpha$-tubulin; (d) loading control stained with Coomassie blue.
$300 \mathrm{nM}$ TSA (figure 5). This result showed that HDACs from class I and HDAC6 specific for tubulin are targets of this compound. ${ }^{29,30}$

Vanini et al described a tetrapeptide $\mathrm{R}^{379} \mathrm{HK}_{\mathrm{Ac}} \mathrm{K}_{\mathrm{Ac}}{ }^{382}$, related to $\mathrm{p} 53$, bound to HDAC8. ${ }^{31,32}$ The alpha amino group of $\mathrm{K}_{\mathrm{Ac}}{ }^{382}$ is positioned close to HDAC 8 Tyr100 and Asp 101, generating hydrogen bounding with the HDAC8 Asp101 residue. An analogous Tyr-Asp pair is found in the bacterial histone deacetylase homologue $\mathrm{HDAH},{ }^{33}$ while it is a Tyr-Glu in HDLP. HDAC1 and HDAC2 have a Glu98-Asp99 pair and HDAC3 a Asp92-Asp93 pair. ${ }^{34}$ These pairs of residues are a common feature in HDAC and were suggested to be important for the development of selective HDACi. The docking of the two conformers $\mathrm{C} 1$ and $\mathrm{C} 2$ of compound $\mathbf{5 b}$ (figure $3 \mathrm{~B}, \mathrm{C}$ ) resulted in a fluorine atom near these pairs of resi-

Table 1. Antiproliferative activities after $48 \mathrm{~h}$ treatment of TSA, SAHA, reported and new TSA derivatives on H661 cells.

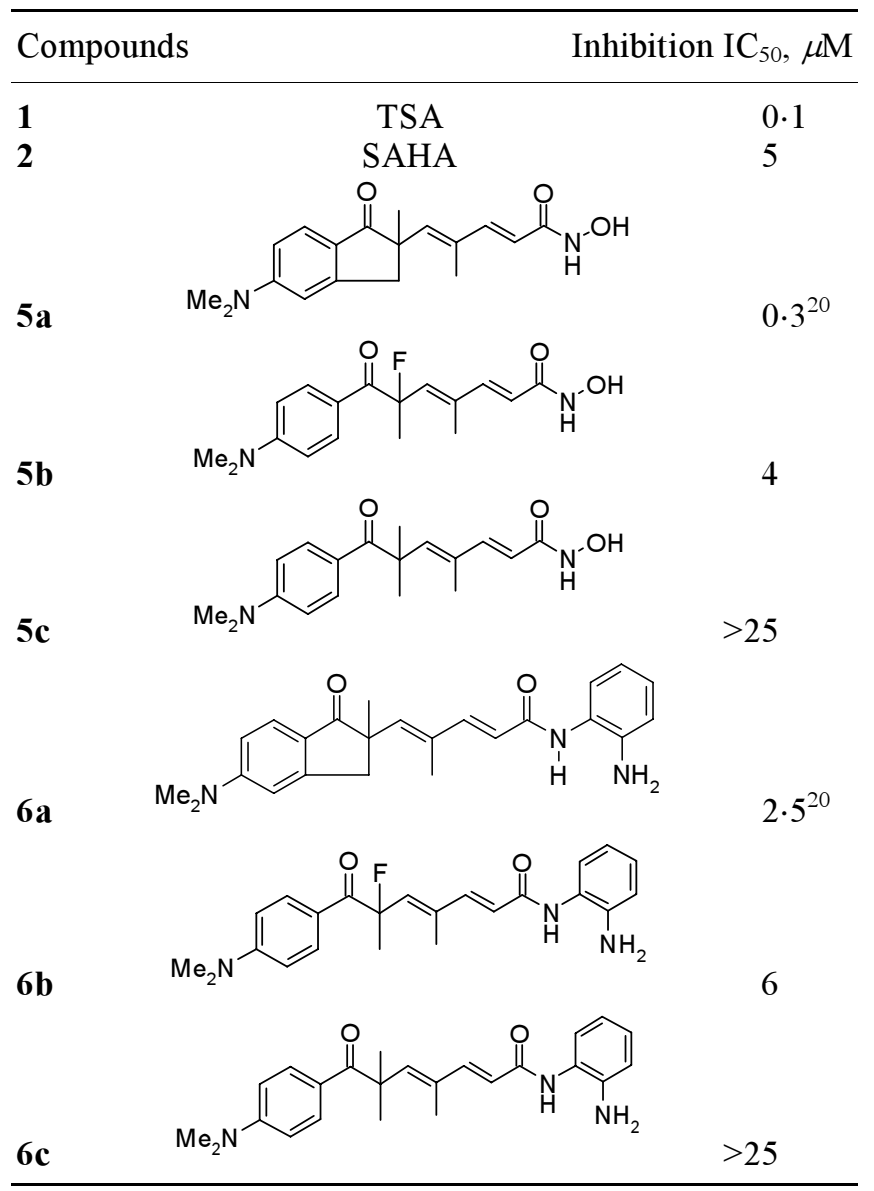

$\mathrm{IC}_{50}$ were determined from the curves of antiproliferative activities (figure 4 ) at the concentration required for $50 \%$ inhibition of cell proliferation. Values are means of two experiments done in triplicate 
dues for both HDAC8 and HDLP. As the fluorine atom is an electronegative element, this possibly resulted in unfavourable electronic interaction with the probably anionic form of the terminal carboxylate found at the entry of the active site (Glu92 in HDLP, Asp101 in HDAC8). On the other hand, it is also possible that the introduction of the fluorine atom increased the hydrophobic properties of the molecule, resulting in a lower cell membrane penetration.

\section{Conclusion}

This work presents a short synthesis of substituted trichostatic acid derivatives allowing the introduction of new functional groups in the alpha position of the ketone group. The methylated derivatives $\mathbf{5 c}$ and $\mathbf{6 c}$ do not show substantial activities while the fluoro derivatives retained antiproliferative activities at micromolar concentrations in our lung cancer cell model. Interestingly, two stable conformers were obtained from modelling for the most active compound $\mathbf{5 b}$, with the first one suitable for docking to HDLP, while the other was found more suitable for HDAC 8 . HDAC inhibitory activity of compound $\mathbf{5 b}$ was confirmed. Work is in progress to develop this synthetic strategy for the production of more potent HDACi.

\section{Acknowledgements}

We thank Ministere de l'Education Nationale et de la Recherche Technologique (MENRT), Centre National de la Recherche Scientifique (CNRS) and La Ligue Contre le Cancer, Comité de CharenteMaritime for financial support.

\section{References}

1. Baylin S B and Ohm J E 2006 Nature Rev. Cancer 6 107

2. Xu W S, Parmigiani R B and Marks P A 2007 Oncogene 265541

3. Bolden J, Peart M and Johnstone R 2006 Nature 5 769

4. Roth S Y, Denu J M and Allis C D 2001 Annu. Rev. Biochem. 7081

5. Hodawadekar S C and Marmorstein R 2007 Oncogene 265528

6. Thiagallingam S 2003 Annu. NY Acad. Sci. 98384

7. Minucci S and Pelicci G 2006 Nature Reviews Cancer 638

8. Rasheed W K, Johnstone R W and Prince H M 2007 Expert. Opin. Investig. Drugs 16659.
9. Dokmanovic M, Clarke C and Marks P A $2007 \mathrm{Mol}$. Cancer Res. 5981

10. Richon V M, Webb Y, Merger R, Sheppard T, Jursic B, Ngo L, Civoli F, Breslow R, Rifkind R A and Marks P A 1996 Proc. Natl. Acad. Sci. USA 935705

11. Marks P A 2007 Oncogene 261351

12. Paris M, Porcelloni M, Binaschi $\mathrm{M}$ and Fattori D 2008 J. Med. Chem. 511505

13. Cheson B D 2006 British J. Cancer $95 \mathrm{~S} 1$

14. Tsuji N, Kobayashi M, Nagashima K, Wakisaka Y and Koizumi K 1976 J. Antibiot. 291

15. Yoshida M, Nomura S and Beppu T 1987 Cancer Res. 473688

16. Yoshida M, Kijima M, Akita M and Beppu T $1990 \mathrm{~J}$. Biol. Chem. 26517174

17. Fleming I, Iqbal J and Krebs E P 1983 Tetrahedron 39841

18. Koseki K and Mori K 1988 Tetrahedron 446013

19. Hosokawa S, Ogura T, Togashi H and Tatsuta K 2005 Tetrahedron Lett. 46333

20. (a) Charrier C, Bertrand P, Gesson J-P and Roche J 2006 Bioorg. Med. Chem. Lett. 16 5339; (b) Charrier C, Roche J, Gesson J-P and Bertrand P 2007 Bioorg. Med. Chem. Lett. 176142

21. Miller T A, Sloman D L, Stanton M G, Wilson K J and Witter D J WO2007087129-A2

22. Frey R R, Wada C K, Garland R B, Curtin M L, Michaelides M R, Li J L, Pease L J, Glaser K B, Marcatte P A, Bouska J J, Murphy S S and Davidsen S K 2002 Bioorg. Med. Chem. Lett. 123443

23. Finnin M S, Donigian J R, Cohen A, Richon V M, Rifkind R A, Marks P A, Breslow R and Pavletich N P 1999 Nature 401188

24. Somoza J R, Skene R J, Katz B A, Mol C, Ho J D, Jennings A J, Luong C, Arvai A, Buggy J J, Chi E, Tang J, Sang B C, Verner E, Wynands R, Leahy E M, Dougan D R, Snell G, Navre M, Knuth M W, Swanson R V, McRee D E and Tari L W 2004 Structure 12 1325

25. Hall S and Weiberth F J 1987 J. Org. Chem. 523901

26. Lawrence N J, Patterson R P, Ooi L-L, Cook D and Ducki S 2006 Bioorg. Med. Chem. Lett. 165844

27. Diwu Z, Beachdel C and Klaubert D 1998 Tetrahedron Lett. 394987

28. Liu P, Chen Y, Deng J and Tu Y 2001 Synthesis 14 2078

29. Hubbert C, Guardiola A, Shao R, Kawaguchi Y, Ito A, Nixon A, Yoshida M, Wang X-F and Yao T-P 2002 Nature 417455

30. Zhang Y, Li N, Caron C, Matthias G, Hess D, Khochbin S and Matthias P 2003 EMBO J. 221168

31. Vannini A, Volpari C, Gallinari P, Jones P, Mattu M, Carfí A, De Francesco R, Steinkühler C and Di Marco S 2007 EMBO Reports 8879

32. Roy S and Tenniswood M 2007 J. Biol. Chem. 282 4765

33. Nielsen T K, Hildmann C, Dickmanns A, Schwienhorst A and Ficner R 2005 J. Mol. Biol. 354107

34. Wang D F, Helquist P, Wiech N L and Wiest O 2005 J. Med. Chem. 486936 